\title{
Evaluation and development of therapeutic management of subacute toxicity of J atropha curcas seed oil in goats
}

\author{
Amit Shukla ${ }^{1}$ and Satyapal Singh ${ }^{2}$
}

1. Division of Pharmacology, Indian Veterinary Research Institute, Izatnagar - 243122, Dist. Bareilly, Uttar Pradesh, India; 2. Department of Veterinary pharmacology and Toxicology, College of Veterinary and Animal sciences,

G.B. Pant University of Agriculture and Technology, Panthangar, Uttaranchal, India

Corresponding author: Amit Shukla, email: princu.dr@gmail.com

Received: 08-08-2013, Revised: 20-08-2013, Accepted: 21-08-2013, Published online: 28-09-2013

doi: 10.14202 /vetworld.2013.852-856

How to cite this article: Shukla A and Singh S (2013) Evaluation and development of therapeutic management of subacute toxicity of J atropha curcas seed oil in goats, Veterinary World 6(11): 852-856.

\begin{abstract}
Aim: The present study was designed to evaluate and develop the therapeutic management for toxicity of Jatropha curcas seed oil in goats.

Materials and Methods: Sub-acute toxicity of $J$. curcas seed oil was evaluated by using nine healthy goats, weighing 28-32 $\mathrm{kg}$ and 16-18 months old, equally and randomly divided in three groups $(\mathrm{n}=3$ per group). Adequate measures were taken to minimize pain to the animals. Group I served as control; they did not receive any treatment. The study was conducted by daily oral dosing of J. curcas seed oil @ 1ml / kg body weight followed by the treatment with the therapeutic module comprising of sodium thiosulphate ( $50 \mathrm{mg} / \mathrm{kg}$ bodyweight ) and glutathione $(0.25 \mathrm{mg} / \mathrm{kg}$ body weight ) in group II; whereas, goats in group III were given daily oral dosing of J. curcas seed oil only for 28 days. Hematobiochemical and antioxidative parameters as Lipid Peroxidase (LPO) and Reduced Glutathione (GSH) in erythrocytes were estimated at day 0, 14 and 28 days.
\end{abstract}

Results: Mild to moderate diarrhoea, dullness, depression and letharginess were observed in all animals in group III, whereas, mild clinical signs were observed in treatment group II. A significant $(\mathrm{P}<0.05)$ decrease in $\mathrm{Hb}, \mathrm{PCV}$, TEC, TLC, total serum protein, albumin and globulin values were observed in group II and III in comparison to the control group I, however, the group II showed increase in the aforesaid parameters in comparison with without group III indicating the therapeutic efficacy of the therapeutic module. A significant $(\mathrm{P}<0.05)$ increase in serum creatinine, serum urea, cholesterol, AST, ALT and ALP were observed in all the groups. Antioxidative parameters in erythrocytes as LPO and GSH increased in group III in comparison to the control and group II.

Conclusion: It is concluded from the above study that therapeutic module comprising of sodium thiosulphate ( $50 \mathrm{mg} / \mathrm{kg}$ IV ) and glutathione $(0.25 \mathrm{mg} / \mathrm{kg} \mathrm{IM})$ in sub-acute study reduces the toxic effects of $J$. curcas seed oil as indicated by the improved Hematobiochemical values in the with treatment group II than the without treatment group III.

Keywords: curcin, Jatropha curcas, phorbol esters, toxicity

\section{Introduction}

Jatropha curcas Linn (Greek:-iatros-doctor, trophe-food), commonly known by various names as Purging nut, Ratanjyot, Physic nut, Barbados nut and Curcas bean is a member of the Euphorbiaceae family and having Central and South American origin and was introduced into Asia and Africa as an oilseed bearing tree by Portuguese seafarers [1]. It is rapid growing and drought resistant plant which grows in poor soil profile as well as in low rain fall area $[2,3,4]$. Investments in fossil fuel can be replaced by cultivating biofuels extracted from perennials grown on abandoned agricultural or degraded lands, as these do not cause a carbon debt at land use change [5,6]. The seed oil of $J$. curcas comprises 33 to $40 \%$ by weight of the seed making the Jatropha bean desirable for biodiesel production [7, 8]. In rural Thailand, $J$. curcas is cultivated close to homes and schools. It produces a yellow fruit which matures into seed pods that fall to

Copyright: The authors. This article is an open access article licensed under the terms of the Creative Commons Attribution License (http://creativecommons.org/licenses/by/2.0) which permits unrestricted use, distribution and reproduction in any medium, provided the work is properly cited. the ground and can be particularly enticing to curious children [9]. Now, Jatropha production is being promoted as a biofuel crop, however the seeds having sweet taste may be hazardous to the people ,children in commonly, engaged in farming [10]. The seeds and seed oil from J. curcas have been reported to produce toxicity due to the toxin curcin, a ricin like toxalbumin, characterized by burning and pain in mouth and throat, vomiting, delirium, decrease of visual capacity and increased pulse with a high mortality rate in rodents and domestic animals $[11,12]$. A number of efforts have been made to explore the therapy of Jatropha curcas toxicity in man and domestic animals without satisfactory outcome. Goats are the hardy animals and in drought conditions they used to eat the seed and leaves and thus become the victim of the poisoning. Different parts of $J$. curcas have wide range of applications in the traditional system of medicine and being practiced as folk remedy for various dermal, digestive, CNS and reproductive disorders of man and animals in several parts of the world. The thiols are associated with gene expression, proliferation, antioxidant defence, erythropoiesis, immunological 
Table-1. Experimental design for subacute toxicity of J atropha curcas seed oil and its therapeutic module in goats ( $n=3$ per group)

\begin{tabular}{|c|c|c|c|}
\hline Groups & Treatment & (Dose) & Days of administration \\
\hline I & Control & & \\
\hline II & Seed oil with Treatment & $\overline{1} \mathrm{ml} / 4 \mathrm{~kg}$ & $\overline{2} 8$ days \\
\hline & Treatment* & & $2-28$ days \\
\hline III & Seed oil without Treatment & $1 \mathrm{ml} / 4 \mathrm{~kg}$ & 28 days \\
\hline
\end{tabular}

* Treatment was comprised of sodium thiosulphate @ $50 \mathrm{mg} / \mathrm{kg}$ body weight, via intravenous (IV)route and glutathione @ $0.25 \mathrm{mg} / \mathrm{kg}$ body weight via intramuscular (I M)route.

response etc. Thus, antioxidants can counteract the oxidative stress, intravascular haemolysis and prevent erythrocyte deterioration that occurs due to toxicity. Sodium thiosulfate acts as a sulphur donor which helps in neutralization of certain free radicals such as $\mathrm{CN}$ from the seed oil is converted to the inactive and soluble thiocyanate which is rapidly excreted in urine. Thiol group is derived from the metabolism of the toxicant as one of the functionally attached moiety.

The aim of the present study is to determine the efficacy of the therapeutic potential for the Jatropha curcas seed oil toxicity in goats.

\section{Materials and Methods}

The Jatropha seed oil used in the experiment were collected from Medicinal Plant Research and Developmental Centre (MRDC), G.B.P.U.A \& T, Pantnagar. All the chemicals were procured from $\mathrm{Hi}$ Media. ERBA diagnostics kits were used for biochemical analysis of serum total proteins, albumin, serum creatinine, urea, cholesterol and enzymatic activities of serum aspartate aminotransferase, alanine aminotransferase and alkaline phosphatise activity.

Ethical approval: Experiment was conducted after the approval in the meeting of December 2011 of the Institutional Animal Ethics Committee.

Experimental design: As illustrated in Table-1, initially, 9 goats of 16 to 18 months of age and $28-32 \mathrm{~kg}$ weight were divided randomly and equally into three groups (n $=3$ per group) and adequate measures were taken to minimize pain or discomfort to animals. Group I was kept as control, Group II and III were given seed oil with treatment $(\mathrm{T})$ and without treatment (WT), respectively. The single oral dose for sub-acute toxicity of the seed oil in group II and III was $1 \mathrm{ml} / \mathrm{kg}$ body weight. Therapeutic module comprised of sodium thiosulphate @ $50 \mathrm{mg} / \mathrm{kg}$ body weight and glutathione @ $0.25 \mathrm{mg} / \mathrm{kg}$ body weight. It is part of our pilot study which we have tested many a times and then we have chose this dose because it proved better in counteract the oxidative stress, intravascular haemolysis and prevent erythrocyte deterioration that occurs due to toxicity. After $14^{\text {th }}$ and $28^{\text {th }}$ day interval the blood samples were collected for Hematobiochemical analysis and antioxidative analysis. Here, we chose to examine the blood parameters for two reasons: 1) as per the IAEC approval no sacrifice was permitted and 2) seed oil produces the intravascular haemolysis and erythrocytic damage as main toxic effects.
Haematology: $4.0 \mathrm{ml}$ of blood was collected from each goat in clean heparinized micro centrifuge tube and haematological parameters such as packed cell volume [13], haemoglobin [13], total erythrocyte count [13] and total leucocytes count [13] were estimated immediately after the collection of blood samples. $0.1 \mathrm{~N}-\mathrm{HCl}$ was used for estimating the blood haemoglobin concentration while, Hayem's RBC diluting fluid and Thomas's WBC diluting fluid were used for TEC and TLC estimation, respectively.

Blood biochemical profile: The serum total proteins, albumin, globulin, total cholesterol, creatinine and urea were estimated by using ERBA diagnostic kits (ERBA Diagnostics, Mannheim Gmbh, Mumbai, Maharashtra, India)

Serum enzyme profile: Serum enzymes viz. aspartate aminotransferase, alanine aminotransferase and alkaline phosphatase were estimated using by using ERBAdiagnostic kits.

Antioxidative parameters in erythrocytes: Parameters for oxidative stress were recorded in erythrocytes. Separation of erythrocyte pellet from blood samples was done immediately after collection of the blood sample. Absorbance of all the estimations was read on UV-VIS spectrophotometer.

The following antioxidative parameters were estimated in erythrocyte collected from the goats using standard protols: a. Lipid peroxidation product malondialdehyde (LPO) [14]. b. Reduced glutathione (GSH) [15].

Statistical analysis: Statistical analysis of data was done by using ANOVA technique. Comparison between treated and untreated groups were made with help of student's' test for all parameters. ANOVA technique was used to compare among groupI ,II and III for all parameters. The results were presented as mean with the standard error. p-value $<0.05$ was considered significant.

\section{Results}

There was mild to moderate weakness, gastric disturbances as diarrhoea, inappetance and letharginess, in group III, whereas, mild clinical signs were recorded in group II starting from day 12 of of administration of the seed oil.

Haematological changes: There was a significant decrease in the values of haemoglobin, packed cell volume, total erythocytic count and total leucocytic 
Table-2. Effect on haematological parameters following daily oral administration of Jatropha seed oil with our without treatment for 28 days in goats (mean \pm S.E., $N=3$ per group).

\begin{tabular}{|c|c|c|c|}
\hline Parameters & group I & group II & group III \\
\hline \multicolumn{4}{|c|}{ Haemoglobin (g\%) } \\
\hline 0 Day & $7.70 \pm 0.189$ & $7.80 \pm 0.063$ & $7.53 \pm 0.012^{\mathrm{a}}$ \\
\hline 14 days & $7.73 \pm 0.039^{A}$ & $7.40 \pm 0.305^{\mathrm{B}}$ & $6.53 \pm 0.240^{\mathrm{ab} \text { АВ }}$ \\
\hline 28 days & $7.63 \pm 0.021^{A}$ & $6.16 \pm 0.635^{\mathrm{B}}$ & $5.40 \pm 0.115^{\mathrm{ab} A B}$ \\
\hline $\begin{array}{l}\text { CD 5\% } \\
\text { PCV }(\%)\end{array}$ & 0.470 & 1.552 & 0.548 \\
\hline 0 Day & $28.00 \pm 1.154$ & $28.46 \pm 0.284^{a}$ & $28.16 \pm 0.452$ \\
\hline 14 days & $27.33 \pm 1.452^{\mathrm{A}}$ & $26.08 \pm 1.154^{\mathrm{B}}$ & $20.00 \pm 1.154^{\mathrm{AB}}$ \\
\hline 28 days & $29.00 \pm 1.527^{A}$ & $22.66 \pm 1.201^{\mathrm{a}}$ & $20.66 \pm 3.179$ \\
\hline \multicolumn{4}{|l|}{ TEC (X 10 $6 / \mu \mathrm{l})$} \\
\hline 0 Day & $11.93 \pm 0.24$ & $11.96 \pm 0.756^{\mathrm{a}}$ & $11.94 \pm 0.089^{\mathrm{a}}$ \\
\hline 14 days & $12.00 \pm 0.118^{A}$ & $8.83 \pm 0.934^{\mathrm{abAB}}$ & $7.73 \pm 0.075^{\mathrm{abAB}}$ \\
\hline 28 days & $11.93 \pm 0.133^{\mathrm{A}}$ & $6.70 \pm 0.076^{\mathrm{abA}}$ & $5.86 \pm 0.128^{\mathrm{abA}}$ \\
\hline $\begin{array}{l}\text { CD } 5 \% \\
\text { TLC }\left(\times 10^{3} / \mu \mathrm{l}\right)\end{array}$ & 0.651 & 1.956 & 0.983 \\
\hline 0 Day & $9.53 \pm 0.176$ & $9.55 \pm 0.062^{\mathrm{a}}$ & $9.52 \pm 0.043^{\mathrm{a}}$ \\
\hline 14 days & $9.50 \pm 0.090^{A}$ & $7.53 \pm 0.133^{\mathrm{aAB}}$ & $7.73 \pm 0.120^{\mathrm{abAB}}$ \\
\hline 28 days & $9.52 \pm 0.018^{A}$ & $6.73 \pm 0.176^{\mathrm{aAB}}$ & $6.20 \pm 0.057^{\text {арАВ }}$ \\
\hline CD $5 \%$ & 0.6 & 0.897 & 0.442 \\
\hline
\end{tabular}

*Treatment with sodium thiosulphate $(50 \mathrm{mg} / \mathrm{kg}$ body weight IV route) and glutathione $(0.25 \mathrm{mg} / \mathrm{kg}$ body weight, I M route)

* Mean values bearing common superscripts with small letters differ significantly $(P<0.05)$ when compared vertically with in the same column and mean values bearing common superscripts with capital alphabets differ significantly $(P<0.05)$ when compared horizontally in the same row.

count as in goup II and III as compare to the control group I. It was observed in the study that the values of the above mentioned parameters were higher in the group II than the group III. The decrease in the above parameters was recorded after $14^{\text {th }}$ and $28^{\text {th }}$ day of administration of the seed oil. The higher values of the above parameters in group II showed that the therapeutic module was ameliorating the adverse effect produced by the seeds of Jatropha curcas (Table-2).

Biochemical changes: There was a significant decrease in the total protein, albumin and globulin values in the group II and III when compared to group I.Whereas, when compared to group III, group II showed a significant increase in the value of the total protein, albumin and globulin after 28 days study. A significant increase in the values of urea, creatinine, cholesterol, AST, ALT and ALP were observed in the treated groups II and III with respect to the control group I after 14 and 28 days of the study. There was decline in aforesaid parameters of seed oil with treatment group II than seed oil without treatment group III (Table-3 and 4).

Antioxidative parameters estimated in erythrocytes: The value of LPO was measured in the form of malondialdehyde ( $\mathrm{nM} \mathrm{MDA} / \mathrm{ml})$ in $\mathrm{RBCs}$. A significant $(\mathrm{P}<0.05)$ increase in the MDA value in
Table-3. Effect on biochemical parameters following daily oral administration of Jatropha seed oil with our without treatment for 28 days in goats (mean \pm S.E., $N=3$ per group).

\begin{tabular}{|c|c|c|c|}
\hline Parameters & group I & group II & group III \\
\hline \multicolumn{4}{|c|}{ Total protein(g/dl) } \\
\hline 0 Day & $7.49 \pm 0.043$ & $7.453 \pm 0.016^{a}$ & $7.48 \pm 0.069^{\mathrm{a}}$ \\
\hline 4 days & 7.49 & & 3.8 \\
\hline 3 days & $7.45 \pm 0.003^{\mathrm{A}}$ & $5.12 \pm 0$ & $2.97 \pm$ \\
\hline $\begin{array}{l}\text { CD } 5 \% \\
\text { Albumin (g/dl) }\end{array}$ & 0.564 & 0.453 & 0.98 \\
\hline 0 Day & 2. & $2.89 \pm 0.056^{a}$ & $2.97 \pm 0.001^{\mathrm{a}}$ \\
\hline & & & \\
\hline & & & \\
\hline $\begin{array}{l}\text { CD 5\% } \\
\text { Globulin(g/dl) }\end{array}$ & & & 05 \\
\hline 0 Day & & & \\
\hline & & & 0.5 \\
\hline 28 & $8^{A}$ & abAB & $1.566 \pm 0.001^{\text {abAB }}$ \\
\hline \multicolumn{4}{|l|}{ Urea (mg/dl) } \\
\hline 0 Day & & 21.5 & $21.40 \pm 0.617$ \\
\hline & & & 29. \\
\hline & & & 46 \\
\hline CD $5 \%$ & 0.4 & & 0.5 \\
\hline \multicolumn{4}{|c|}{ Creatinine $(\mathrm{mg} / \mathrm{dl})$} \\
\hline 0 Day & 0 & & 0.74 \\
\hline & & & 0.6 \\
\hline & & $2.31 \pm c$ & $.008^{\mathrm{abAB}}$ \\
\hline & 0.4 & 0.23 & 0.456 \\
\hline \multicolumn{4}{|c|}{ Cholesterol(mg/dl) } \\
\hline 0 Day & 58 & 58.9 & 58. \\
\hline 14 days & & & $39.28 \pm 0.003^{\mathrm{abAB}}$ \\
\hline & & & \\
\hline & & & 0.1 \\
\hline
\end{tabular}

*Treatment with sodium thiosulphate $(50 \mathrm{mg} / \mathrm{kg}$ body weight IV route) and glutathione $(0.25 \mathrm{mg} / \mathrm{kg}$ body weight, I M route)

* Mean values bearing common superscripts with small letters differ significantly $(P<0.05)$ when compared vertically with in the same column and mean values bearing common superscripts with capital alphabets differ significantly $(P<0.05)$ when compared horizontally in the same row.

groups II and III was observed in comparison to group I on $28^{\text {th }}$ day interval. The value of GSH was measured in the form of $\mu \mathrm{M} / \mathrm{ml}$ in RBCs. A non-significant change in the GSH level was found in groups II and III, as compared to control. There was a significant $(\mathrm{P}<0.05)$ decrease in GSH value in group II in comparison to groups III on both $14^{\text {th }}$ and $28^{\text {th }}$ day interval (Table-5).

\section{Discussion}

The appearance of the clinical signs in seed oil intoxicated goats might be due to the higher concentration of diterpenes, curcin, tannin, sterol, phorbol esters in oil which is known for its purgative effect [17], that occurs due to its stimulating effect on protein kinase-C enhancing intracellular signal transduction process [18]. Curcin is known to cause direct gastrointestinal tract (GIT) irritation and cellular toxicity [19] which might be responsible for toxicity manifestation such as hepatotoxicity and nephrotoxicity in goats. Low level of toxic manifestation in groups treated with the therapeutic module reveals the therapeutic potential of the treatment regimen.

Hematological parameters such as $\mathrm{Hb}, \mathrm{PCV}$, TEC and TLC decreased in seed oil intoxicated groups in sub-acute toxicity. Decrease in Hb, PCV, TEC and TLC might be due to haemolytic activity of curcin 
Table-4. Effect on serum enzymatic activities following daily oral administration of Jatropha seed oil with our without treatment for 28 days in goats (mean \pm S.E., $N=3$ per group).

\begin{tabular}{llll}
\hline Parameters & group I & group II & group III \\
\hline AST (U/L) & & & \\
0 Day & $25.25 \pm 0.996$ & $25.14 \pm 0.480^{\mathrm{a}}$ & $25.05 \pm 0.200^{\mathrm{a}}$ \\
14 days & $24.80 \pm 0.012^{\mathrm{A}}$ & $39.36 \pm 0.002^{\mathrm{abAB}}$ & $47.06 \pm 0.073^{\mathrm{abAB}}$ \\
28 days & $24.92 \pm 0.011^{\mathrm{A}}$ & $49.18 \pm 0.013^{\text {abAB }}$ & $69.38 \pm 0.370^{\text {abAB }}$ \\
CD 5\% & 1.98 & 0.234 & 0.945 \\
ALT(U/L) & & & \\
0 Day & $16.25 \pm 0.044$ & $16.27 \pm 0.635^{\mathrm{a}}$ & $16.33 \pm 0.207^{\mathrm{a}}$ \\
14 days & $16.44 \pm 0.220^{\mathrm{A}}$ & $29.32 \pm 0.024^{\text {abB }}$ & $33.16 \pm 0.003^{\mathrm{a} \text { a AB }}$ \\
28 days & $16.33 \pm 0.005^{\mathrm{A}}$ & $45.17 \pm 0.005^{\text {abAB }}$ & $50.66 \pm 0.365^{\mathrm{a}, \mathrm{bAA}}$ \\
CD 5\% & 0.454 & 0.112 & 0.632 \\
ALP (U/L) & & & \\
0 Day & $67.54 \pm 0.012$ & $67.48 \pm 0.012^{\mathrm{a}}$ & $67.29 \pm 0.107^{\mathrm{a}}$ \\
14 days & $67.18 \pm 0.005^{\mathrm{A}}$ & $65.12 \pm 0.045^{\mathrm{abB}}$ & $67.07 \pm 0.021^{\text {bAB }}$ \\
28 days & $67.45 \pm 0.105^{\mathrm{A}}$ & $70.64 \pm 0.009^{\text {abAB }}$ & $73.13 \pm 0.236^{\text {abB }}$ \\
CD 5\% & 0.345 & 0.987 & 1.23 \\
\hline
\end{tabular}

*Treatment with sodium thiosulphate $(50 \mathrm{mg} / \mathrm{kg}$ body weight IV route) and glutathione $(0.25 \mathrm{mg} / \mathrm{kg}$ body weight, I M route)

* Mean values bearing common superscripts with small letters differ significantly $(P<0.05)$ when compared vertically with in the same column and mean values bearing common superscripts with capital alphabets differ significantly $(\mathrm{P}<0.05)$ when compared horizontally in the same row.

which causes ricin like action and disturb the normal protein synthesis reaction by altering the affinity and reaction going pass through the ribosomes subunits. Furthermore, damage to the GIT could also have resulted in maldigestion and malabsorption of nutrients required for erythropoiesis [20]. Leucopoenia might be resulted due to antinutritional factors as tannins, saponins, phytates etc along with the stress. Similar findings were reported following Jatropha intoxication in rats at the dose rate of 25\% Jatropha seed protein on $7^{\text {th }}, 14^{\text {th }}$ and $22^{\text {nd }}$ day [21] and in rabbits receiving 5\%, 7.5\% and 10\% Jatropha seed meal for 6 weeks [22]. There was an increase in urea and serum creatinine level in seed oil intoxicated groups indicating the nephrotoxic potential of Jatropha as urea and creatinine act as indicators of the renal damage. In the present study, treatment significantly reduced the level of urea and creatinine in group II indicating the protective effect of therapeutic module on renal system. A significant increase in serum cholesterol level was observed in seed oil intoxicated group in study. Liver is the major site of cholesterol synthesis and metabolism. Hepatic cholesterol homeostasis is maintained by equilibrium with activities of hydoxy methyl glutryl coenzyme A reductase and acyl coenzyme A cholesterol acyl transferase.

The rise in activity of serum AST, ALT and ALP enzymes could be attributed to the damaged structural and cellular integrity of the hepatocytes and due to centrilobular necrosis which in turn increased the leakage of the liver specific enzymes.

There was a significant reduction in the GSH value in seed oil with treatment group in comparison with the seed oil without treatment group on $14^{\text {th }}$ and $28^{\text {th }}$ day interval. The exogenously given glutathione in the therapeutic module itself served as an oxidizing agent that might have reduced the free radical
Table-5. Effect on antioxidative parameters following daily oral administration of Jatropha seed oil with our without treatment for 28 days in goats (mean \pm S.E., $N=3$ per group).

\begin{tabular}{|c|c|c|c|}
\hline Parameters & group I & group II & group III \\
\hline \multicolumn{4}{|c|}{ LPO (nM MDA/ml) } \\
\hline 0 Day & $19.66 \pm 0.025$ & $19.36 \pm 0.192^{\mathrm{a}}$ & $19.50 \pm 0.128^{a}$ \\
\hline 14 days & $19.98 \pm 0.601^{\mathrm{A}}$ & $28.16 \pm 0.245^{\mathrm{a}}$ & ${ }^{\mathrm{AB}} 31.60 \pm 0.239^{\mathrm{ab} \mathrm{AB}}$ \\
\hline 28 days & $19.18 \pm 0.596^{A}$ & $37.14 \pm 0.953^{\mathrm{ab}}$ & ${ }^{A B} 46.78 \pm 0.640^{\text {ab } \mathrm{AB}}$ \\
\hline $\begin{array}{l}\text { CD } 5 \% \\
\text { GSH }(\mu \mathrm{M} / \mathrm{ml})\end{array}$ & 1.090 & 1.964 & 1.381 \\
\hline 0 Day & $2.65 \pm 0.006$ & 2.64 & $2.62 \pm 0.020$ \\
\hline 14 day & $2.65 \pm 0.00^{A}$ & $2.54 \pm 0.047^{\mathrm{A}}$ & $2.60 \pm 0.012$ \\
\hline 28 days & $2.64 \pm 0.017$ & $2.60 \pm 0.035$ & $2.62 \pm 0.026$ \\
\hline CD 5\% & 0.371 & 0.122 & 0.635 \\
\hline
\end{tabular}

*Treatment with sodium thiosulphate $(50 \mathrm{mg} / \mathrm{kg}$ body weight IV route) and glutathione ( $0.25 \mathrm{mg} / \mathrm{kg}$ body weight, I M route)

* Mean values bearing common superscripts with small letters differ significantly $(P<0.05)$ when compared vertically with in the same column and mean values bearing common superscripts with capital alphabets differ significantly $(\mathrm{P}<0.05)$ when compared horizontally in the same row.

formation and in turn decreased the endogenous generation of the GSH. The result indicate that the glutathione provided a better relief in terms of oxidative stress to the goats. The thiols such as cysteine derivatives, glutathione, lipoic acid and ergothioneine are involved in production of reactive oxygen species (ROS) which are associated with gene expression, proliferation, antioxidant defence, erythropoiesis, and immunological response. Thus, antioxidants can counteract the pro-oxidants, intravascular haemolysis and prevent erythrocyte deterioration. Sodium thiosulfate acts as a sulphur donor which help in neutralization of certain free radicals such as cyanide radicals from the oil is converted to the inactive and soluble thiocyanate which is rapidly excreted in urine.

Oxidative stress is characterized by increased lipid peroxidation (LPO) and or altered non enzymatic and enzymatic antioxidative systems. LPO of membrane is regulated by the availability of substrate in the form of polyunsaturated fatty acids (PUFA), the availability of inducers such as free radicals and the excited state molecules to initiate propagation, the antioxidant defense status of environment and physical status of membrane lipids [23]. The present study showed that exposure to toxicity stress resulted in increase in LPO levels in erythrocytes as evidenced by the increased production of malondialdehyde (MDA) and increased intravascular damage to the erythrocytes. Curcin, also an toxalbumin like Ricin may induce DNA damage, oxidative stress and thyroid toxicity with necrosis in rats [24]. The phorbol esters, present in seed oil have been reported to interfere with the activity of protein kinase $\mathrm{C}$ that affects a number of processes including phospholipid and protein synthesis, enzyme activities, DNA synthesis, phosphorylation of proteins, cell differentiation and gene expression [25] . 


\section{Conclusion}

It is concluded from the above study that the clinical manifestations of the sub-acute toxicity of seed oil appeared after $14^{\text {th }}$ post exposure in goats that did not receive any treatments (group III). The therapeutic module comprising of sodium thiosulphate $(50 \mathrm{mg} / \mathrm{kg}$ IV) and glutathione $(0.25 \mathrm{mg} / \mathrm{kg}$ IM) in sub-acute study improved the values of Hematobiochemical parameters after $14^{\text {th }}$ day of study.

\section{Authors' contributions}

Both authors contributed equally. Both authors read and approved the final manuscript.

\section{Acknowledgements}

The authors are pleased to thanks the Defence Research and Development Organisation, New Delhi, India for financial assistance for conducting this study.

\section{Competing interests}

The authors declare that they have no competing interests.

\section{References}

1. Heller, J. (1996) Physic nut. Jatropha curcas Linn, promoting the conservation and use of underutilized and neglected crops. PhD dissertation. Institute of Plant Genetics and Crops Plant Research, Gatersleben International Plant Genetics.

2. Ishii, Y., Takeuchi, R. and Tokida, K. (1987) Transesterified curcas oil as a farm diesel engine fuel. In: Proceedings of the international symposium on agriculture mechanization and international co-operation in the high technology era. 239. University of Tokyo.

3. Munch, E. and Kiefer, J. (1989) Purging nut (J. curcas L) Multi-use plant as a source of fuel in the future. Schriftenreihe der GTZ. 209; 1-32.

4. Ye M., Li C., Francis G., Makkar H.P.S. (2009) Current situation and prospects of Jatropha curcas as a multipurpose tree in China. Agroforestry Systems.; 76:487-497.

5. Fargione, J., Hill, J., Tilman, D., Polasky, S., Hawthorne, P., (2008) Land clearing and the biofuel carbon debt. Science $319,1235-1238$

6. Searchinger, T., Heimlich, R., Houghton, R.A., Dong, F.X., Elobeid, Fabiosa, J., Tokgoz, S., Hayes, D., Yu, T.H., (2008) Use of US croplands for biofuels increases greenhouse gases through emissions from land-use change. Science 319, 1238-1240.

7. Berchmans H. and Hirata S. (2008) Biodiesel production from crude Jatropha curcas L. seed oil with a high content of free fatty acids. Bioresour Technol; 99: 1716-21.

8. Patil P. and Deng S. (2009) Optimization of biodiesel production from edible and non-edible vegetable oils. Fuel; 88: 1302-6.
9. Devappa RK, Makkar HPS, Becker K. (2010) Jatropha toxicity-A review. J Toxicol Environ Health, Part B: Crit Rev; 13:476-507.

10. Agarual A. and Saxena M. (2011) Der Chemica Sinica, (2), $172-176$.

11. Rai, D. and Lakhanpal, P. (2008) Jatropha curcas poisoning in pediatric patients, Mauritius. Internet J. Pediatrics Neonatol. 8: 1-6.

12. Singh, R., Singh, D. and Mahendrakar, A. (2010) Jatropha poisoning in children. Med. J. Armed Forces India, 66: $80-81$.

13. Jain, N. (1986) Schalm's Veterinary Haematology. $4^{\text {th }}$ Ed. Philadeiphia, Lea and Febringer, Page no. 61-63.

14. Rehman, S.U. (1984) Lead induced regional lipid peroxidation in brain. Toxicol. Lett. 21:333-337.

15. Prins, H.K. and Loos, J.A. (1969) Glutathione, In: Yunis, J.J. ed. Biochemical methods in red cell genetics. New York, Academic Press. 115-137.

16. Snedecor, G.W. and Cochran, W.G. (1989) Statistical Methods. $8^{\text {th }}$ ed. Ames, Iowa State University Press. Page no. 256-298.

17. Gendler, S. (1984) Proteins, in clinical chemistry: Theory, analysis and correlation, Toranto, 1268-1327.

18. Warnick, G., Nguyen, T. and Alberts, A. (1985) Comparison of improved precipitation methods for quantification of high density lipoprotein cholesterol. Clin. Chem., 31: 217.

19. Lin, J., Zhou, X., Wang, J., Jiang, P. and Tang, K. (2010) Purification and characterization of curcin, a toxic lectin from the seed of Jatropha curcas. Prep. Biochem. Biotechnol., 40(2): 107-18.

20. Chivandi, E., Erlwanger, K.H., Makuza, S.M., Read, J.S. and Mtimuni, J.P., (2006) Effects of dietary Jatropha curcas meal on percent packed cell volume, serum glucose, cholesterol and triglyceride concentration and alphaamylase activity of weaned fattening pigs. Res. J. Anim. Vet. Sci., 1: 18-24.

21. Awasthy, V., Vadlamudi, V., Koley, K., Awasthy, B. and Singh, P.(2011) Biochemical changes after short-term oral exposure of Jatropha curcas seeds in wistar rats. Toxicology international, 17 (2): 67-70.

22. Abdel-safy, S., Nasr, S., Abdel, R. . and Habeeb, S. (2011) Effect of various levels of dietary Jatropha curcas seed meal on rabbits infested by the adult ticks of Hyalomma marginatum I. Animal performance, anti-tick feeding and haemogram. Trop. Anim. Hlth. Prodn., 43(2): 347.

23. Pipicelli, O., Fedele, E., Berardi, M., Raiteri, M., Levi, G., Greco, A., Ajmone-Cat, M.A. and Minghetti, L. (2005) Cyclo-oxegenase- 1 and 2 differently contribute to prostaglandin E2 synthesis and lipid peroxidation after in vivo activation of $\mathrm{N}$ Methyl-d-aspartate receptors in rat hippocampus. J. Neurochem., 93: 1561-1567.

24. Kumar, O., Lakshmana, R.P.V., Pradhan, S., Jayaraj, R., Bhaskar, A.S., Nashikkar, A.B. and Vijayaraghavan, R. (2007) Dose dependent effect of ricin on DNA damage and antioxidant enzymes in mice; Cell. Mol. Biol., 53(5): 92-102.

25. Makkar, H.P.S. and Becker, K. (2009) Jatropha curcas, a promising crop for the generation of biodiesel and valueadded coproducts. Eur. J. Lipid Sci. Technol., 111: 773-787. 